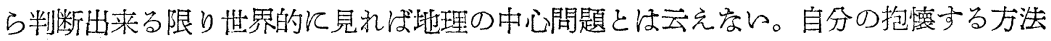
論によって真面目な研究を行ら，とれを発表するのが科学者の態度である。 (4) 漁 業はポルトガルであったから 7 篇も出たのであって, 世界的に見れば微々たる存在で あるにすを゙ない。今回のワシントンでもとうであったと云得ると考光る。(5) と れに反して聚落は常に一つの焦点となって居る。土地に根ざしたものが地理の伝統で あるとしタじ俞感ぎざるを得ない。（6）歴史地理の論交は 3 篇だけで，それもとと ごとく有史以前の問題を取扱って居り，他は地理学史関係のものばかりで方る。 地理教育はらつでも低調である。教育でも論ずるより能のない人のためと設けてある 部会という感がある。(8) 仏語が圧倒的に使われるととは上の数字が雄弁泌物語っ て居る。次回のブラジルでは恐らくこの傾向は強く崇って, 多少独語が進出する位で あろう。（9）英語と米語とに分けて統計を取って見るととは出来枽かったが，この 両方が同じ感覚で使われて居るという錯覚に陷らぬととが大切である。特に米語の会 話のタと長ずる人々を警めたら。

この沢山な論文が皆読めるものでもないし，必要なものは引用なり抄録宗りによる ととつし，てっでは論交の内容には一切触れなかった。全論文の題目訳交のリストを 作るだけでも一仕事である。

(今 村 学 郎)

\title{
二, 三の歴史地理書
}

戦後10年にして漸く地理学内での各部門別の専門書や，對書が出版されだしたこと は喜ばしい。歴史地理方面においても，既に名のあるドイッのハツシンガーやイギリ スのイースト等ヨーロッパの歴史地理の概説書の重版が出されたほか，ドイッではシ ュリューターの中欧の先史地図を主とした先史及び古代景観の研究の遺稿が Forschungen zur Deutschen Landeskunde の1冊として出ている。原名は Die Siedlungsräume Mitteleuropas in Frühgeschichtlicher Zeit 1952 年である。僅か そ50頁程度の小冊であるが，内容は I Naturlandschaft, Urlandschaft, Altlandschaft, II Inhalt u. Darstellungsweise der Karte, III Die Wissenschaftlichen Grundlagenの3 部にわかれ，結局は先史地図の完成を企図したものである。その方 法は交献や地名 (Ortsnamen), 集落耕地の形態 (Siedlungs-u. Flurformen), 先史 遺跡 (Vorgeschichtsfunde), 自然的条件等を, 現在の地表一具体的には 1 枚の地 罒一に表現せんとしたもので，あくをでらわゆる中間にたつ時間を克服したいわゆる 
シュリューター式の歴史地理である。

つぎにイギリスでこ〉2〜3年中に発行されたものの中で筝者が最近手にしたもの を二三丨げてみる。をず O.G.S. Crawford; Archaeology in the Field, 1953. これは Geographical Journal にも批評が出ていたように地理学者が読むべき考古 学書である。日本でも遺跡景観とらう言葉が使用されるが, 正と本畫の中には珍らし ら各地の遺跡が, 上手写写真におさめられている。著者は雑誌 Antiquity の主幹で あり，且つイギリスの Ordnance Survey の技師として，考古地図の作製と名のある 学者であり, 且つ航空写真の利用者として著名である。23章から成当本書では, あく まで Field Archaeology の重要さ竞語り，且つ具体的に示している。とりわけ筙 5 , 6, 7章を Roman Road の研究㵒し, 浪かに Roman Earthworks (第16章) が, 新石器時代の巨石記念物 (Megalithic Monuments) (第15章) と一緒て取扱れてい る。またケルト時代の耕地の二, 三を復原し，集落遺跡としてね，各種の住居址，洞 窟基地等と共に Ponds や Camps 等にふれている。との後者は地理学に興味の宗い 考古学者には今迄は問題にもされなかったととろである。更に彼の與味は中世の今は 廃墟景観となった城墟や公園, それと耕地にも及ぶ。B 6 倍版 250 頁にも及ぶ大册で あり，以前に小田内通敏によって紹介された彼の“Man and his Past”(1921）の㝬 証版といらととが出来よう。

このほか概説的歴史地理畫が 2 つ出ている。一は J. M. Houston；A Social Geography of Europe. 1953.であり，他は J. B. Mitchell; Historical Geography. (The Teach Yourself Books) 1954である。まず前者はその名は社会地理学ではあ るが, 内容は村落と都市, 人口䦗題 (Population Studies) の3 部から成り, 新し々 社会地理である。すをわち. “Social Geography must be more associated with historical methods”とあり, 内容また現在の中に過去の歴史を読夕とらんとする広義 の歴史地理畫であり, 前号の本誌にも紹介せられた。乙れて対して後者すなっち Mitchel1 の畫物は叢書の一つをなし，歴史地理学の何たるかを示さんとしたもので西る。 従って地理学に利りる歴史地理学の立場を最初にのべ, また資料や研究法（第 2 章） に及ぶ点等は，従来のこの種の書物にはみられ交かったととろである。たが例証の範 囲がイギリスに限られてはいるが，内容は充実して和り，集落（都付をふくさ），工業， 交通とらった項目别に，しかも編年的叙述を試みる。とりわけ第 6 の The Changing 
Geography of the Countryside の名で歷史時代に利りる森林, 沼沢地の開発過程 をのべたもの等, 日本の新田研究の地理学的立場等に参考になる。その他, 地名の研 究がイギリスでは案外重要であることが，本書の中にらから゙われる。

以上の质か地理的学歴史書としては例充ばオックスフォード大学の J. L. Myres;

Geographical Mistory in Greek Lands. 1953等が出ている。

これはその交字の如く歴史の考証の手段としての地理的研究で, われわれのいわゆ る歴史地理とは趣き異にする。しかし人口の推定等古交献からする考証等は歴史地

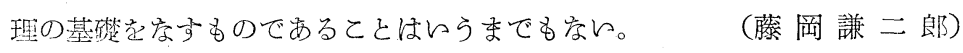

August Lösch; The Economics of Location. translated by William $H$.

Woglom (Yale University Press, New Haven, ) 1954. 520p.

本畫の原畫は Die räumliche Ordnung der Wirtschaft といいそその初版は1939年 に出た。すでにドイッは第 2 次世界戦争に突入してらたが，幸にわたくしの所属する 京大農経教窒に届いた。経済諸活動の立地を中心に，経済と空間との関係を統一的理 諭的に把握しょうとするものであって，まさしく経済立地学や経済地理学の新しい道 学開こらとするものと考元られた。

ととらが，当たくしは全然知らなかったが，戦争のまっただなかの1943年にとの第 2 版が出た。乙の Lösch の業績はアメリカでも非常に高く評価されたが，わが国に おらてと同様，なににせよ原畫はなか索か入手しがたかったそらである。それらの関 係で，とのたびとの第 2 版が英訳された。乙の英訳書は一瞥しただけであるが，きわ

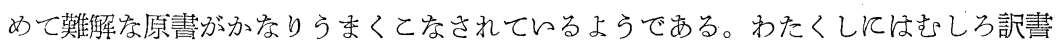
の经らがわかりやすい゙うに思われる。経済立地学なり経済地理学の最近の理論的交 献としては最も注目されるべをである。

訳㩇の巻頙には原著者とともに Bonn にふらて Schumpeter 教授のもとに学んだ 親友の Michigan 大学 Stolper 教授の追想交が載せられてある。

それによると Lösch は大戦中も終始 Kiel の Weltwirtschaftsinstitut で研究索 つづけたが，1945年5月，39才にして浙去したそらである。まととに惜しみて余りあ るものがある。

(本 岡 武) 